\title{
Building Synergism through Cluster Strategy in Developing the Weaving Industry
}

\author{
Khasan Setiaji ${ }^{1{ }^{*}}$, Kardoyo $^{1}$, and Nofan Farid Maghfuri ${ }^{1}$ \\ ${ }^{1}$ Universitas Negeri Semarang, Semarang - Indonesia
}

\begin{abstract}
Industrial sector as a main drive of the Indonesian economy has a challenge to build a synergy between industrial business actors. This study aims to determine the pattern of relationship in the weaving industry; to identify the cluster strategies in the weaving industry; to analyze the supporting and obstructing factors of the cluster strategy. This study uses a qualitative approach, i.e. case study type. Data in this study were collected from industries of Troso weaving. The results show that there are three patterns of relationship: cooperative, supportive and non-supportive between small, medium and large industries. Cluster strategies in the development of weaving industry are applied through inter-industry cooperation, availability of raw material input and supporting materials which indicate that the cluster has shown efficiency and synergy in production process as the majority of labor input comes from within the cluster. Local government supports, local community wisdom, locations, availability of skilled workforce and technologies become the factors that support the successful cluster strategies. While the capital, management, competition, marketing, and industrial relations are still great constraints.
\end{abstract}

Keywords: Cluster; Synergy; Industry.

\section{Introduction}

The world has developed into one which makes industry into a potential alternative source of economy. It is important to generate ideas and creativity in order for this sector to continue to develop and become a drive in Indonesia's economy[1]. The production factors influencing the industry's development include capital, workforce, raw materials, transportation, sources of energy or fuel and marketing[2].

Industrial development is often associated with the development of a region. This is due to the multiplier effects and innovations generated by industrial activities interacting with potential and constraints. Industry is often the main enemy for the environment, for this reason certain mechanisms are needed so that the environment in which the industry is located is not disrupted. Industry players must take measures to prevent environmental pollution by carrying out clean technology, installing pollution prevention tools, carrying out the recycling process and most importantly having to process industrial waste in order to eliminate pollution materials or at least minimize pollution up to the permissible limits. Sustainable development can be formulated as a conscious and planned effort that integrates the environment, including its resources into a development process that guarantees the ability, welfare and quality of life of present and future generations [12].

In Indonesia, woven fabric is a product of craftsmanship belonging to processing industrial sector. Some regions are well-known for their woven fabric production such as West Sumatera, Palembang, and West and Central Java. Jepara, a regency in Central Java Province, is one of woven fabric producers. Their woven fabric is known as Troso which sits in the second place of the regency's superior products at a total production value of Rp.481,798,724,000 after wooden furniture industry. Jepara's Troso woven fabric has reached both foreign and domestic markets[3]. The effort that the Jepara's local government has made to develop weaving industry is establishing Troso Village as a Tourism Village for Ikat Weaving Attraction. In addition, the weaving business actors cooperate in a cluster to maximize its production and sales. Jepara's Troso weaving industry consists of small, medium, and large enterprises. Mei suggests that most business development is centralized around the superiority strategy of each business itself[4]. There is a need to build a mutualistic cooperation to prevent unfair competition between small, medium and large enterprises. Evi in her research states that

*Corresponding author: setiaji@mail.unnes.ac.id 
it is necessary to take the steps of developing clusters from local market orientation typology to local network so that the cluster's presence can benefit both businessmen and craftmens of medium and small enterprises[5]. Cluster strategy is deemed appropriate to develop the industry. As suggested by Porter, the recent economic map is dominated by the so-called cluster[6]. Similar opinion is also stated by Kuncoro who believes that industries tend to agglomerate in regions wherein they have the potential benefits as a result of adjacent company's locations[7].

The research aims at describing how the synergism among industrial actors is through cluster strategies in developing Jepara's Troso weaving industry.

\section{Methodology}

This is a qualitative study. It focuses on the characteristics of relationships of weaving industry; cluster strategy of weaving industry; supporting and obstructing factors of cluster strategy. The research is conducted in the cluster area of weaving industry at Troso Village, Jepara Regency, Indonesia. This research's object is the weaving enterprises in Troso Village which are selected using purposive sampling method amounting to 70 weaving enterprises consisting of 8 large enterprises, 20 medium enterprises, and 42 small enterprises. The data are taken using observation, interview and documentation study. In this research, Dependability and Credibility Tests with Member Check and Source Triangulation are used[8].

\section{Discussion}

Inside Troso weaving industry cluster area, there is a characteristic of pattern of weaving industries which forms a relationship pattern of small, medium, and large industries which relates one to another.

The first relationship pattern is between small industries and small and medium industries which is of cooperative nature in sharing information on price and bestselling motif applicable in the market. Furthermore, the small industries have a relationship of supporting each other with large industries in terms of product sales, where the small-sized industries, in addition to selling their products independently, also supply them to the showrooms owned by large industries. Secondly, the relationship pattern between small industries and medium industris is supporting each other in regard to information on product sales such as business exhibition and training held by the government. Meanwhile, the relationship pattern between medium industries and large industries is of opposite nature as characterized by competition between them, driving them to develop the technology in their possession, including in such fields as marketing, production, and training. Moreover, the relationship pattern between medium industries and small industries is of cooperative one to another to determine the price of woven fabric in the market as well as information on products. Thirdly, the relationship pattern between large industries and their fellow large and medium industries is of opposite nature, where there is a competition between large industries; they stand firm with their abundant capital and production outcomes, possession of their own market shares. Meanwhile, their relationship pattern with small industries is of supporting each other, where most large industries will cooperate with small industries when they fail to meet their customer's demand for woven fabric to cover it.

In essence, industrial cluster is more than just a group of industries located in a certain place. Beyond being in one place, cluster means linkages between these industries, both vertically and horizontally. Through these linkages, these industries do more than compete among themselves, rather they also cooperate. Discovering this cluster pattern, the decision makers could then make an approach to develop the industries.

Troso weaving industry cluster results in positive image. The industries' locations are concentrated in Desa Troso, giving people an image which make it easier for them to refer Troso Village as the ikat weaving producing village. This will attract potential buyers to come and purchase or merely observe the attraction of making the ikat woven fabric. Furthermore, Troso weaving cluster can also attract buyers ordering in large number, believing that their order will be successfully fulfilled by these industries.

The geographic site of Troso weaving industries are adjacent one to another, making it easier for them to give a working contact to suppliers and subcontractors to meet large production need with supply and the need for raw materials inside the cluster, then it is highly likely for suppliers to come and make an offering[9]. This will faciliate the industries to obtain raw materials. Being located within Troso weaving industry cluster will drive experienced workforce originating from Troso Village to gather. In turn, this makes it easier for the industries to recruit the workforce from within the industrial cluster itself. Troso weaving industry can absorb 1700 people with mostly coming from within the cluster.

The weaving industries inside the Cluster cooperate one another in obtaining information on price, market, business partners etc. The relations among these industries inside the cluster is dynamic. This is characterized by the establishment of Troso weaving association which aims at dealing with problems the businessmen are encountering, including the capital issues, technology and 
marketing of Troso woven fabric products. The adjacent geographic locations of these weaving industries enable them to enjoy the easy way of obtaining raw materials and workforce. In addition, this will also also allow them to share information. However, the level of cooperation is relatively low because out of 70 Troso weaving industries only $35.7 \%$ cooperate one another in sharing information. The existence of Troso weaving industry cluster creates some relationship patterns both vertically and horizontally between the industries and the supporting components which are interrelated within the cluster. For a clearer illustration of Troso weaving industry cluster, please refer to the following figure.

We can see that there are circles which represent the regional levels starting from Troso Village which constitutes the Troso weaving cluster area, in which it is divided into large, medium, and small weaving industries

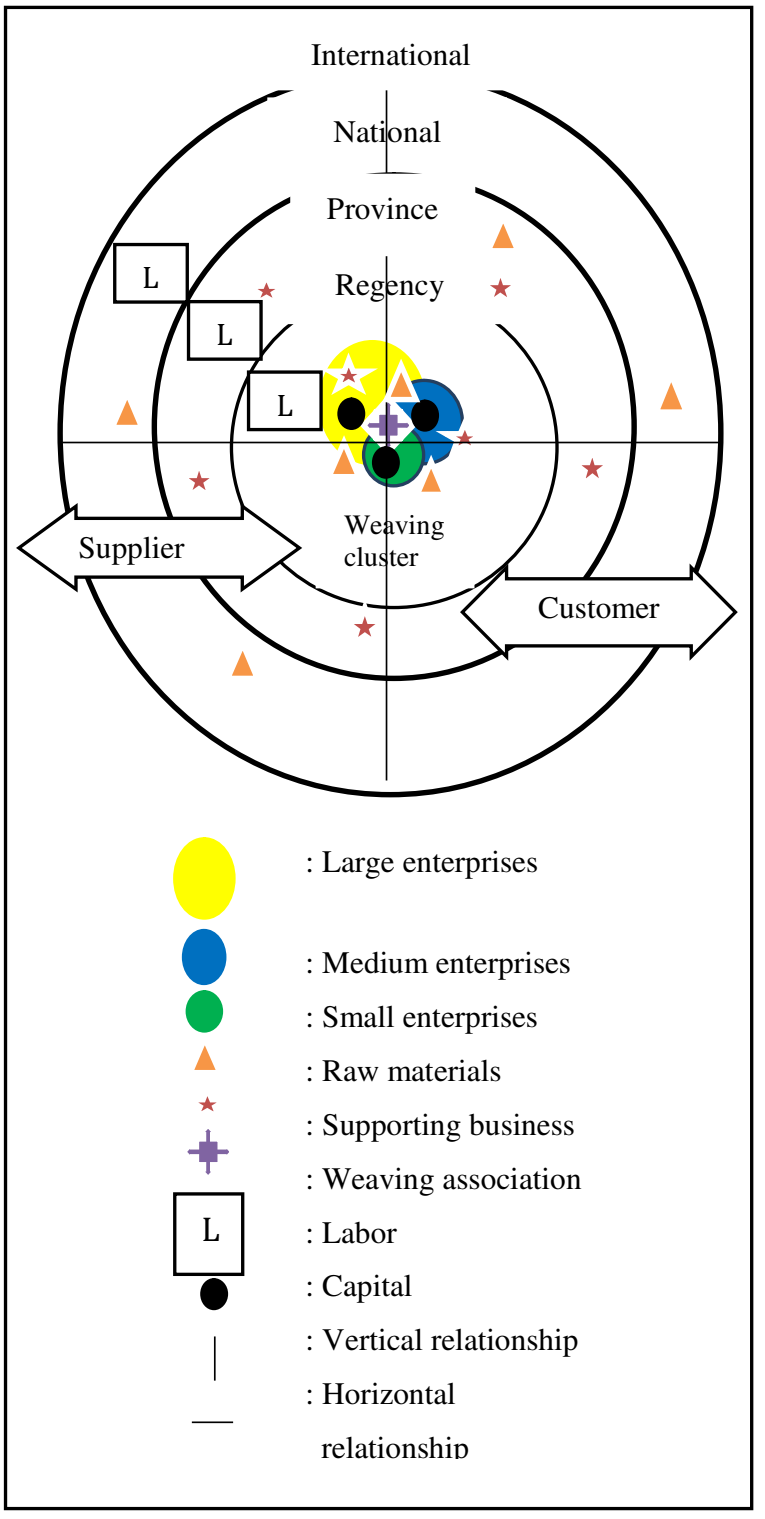

Fig. 1. Cluster Strategy in Troso Weaving Industry Development
The next ones are Jepara regency, Central Java province, and finally Indonesian national territory. The further the circle the weaker its relationship with the cluster.

The supplier input for Troso weaving cluster can be seen in the figure, which include input of raw materials and supporting businesses and workforce. For supporting businesses, their availability resides within the two innermost circles, i.e. within the Troso weaving cluster itself and Jepara Regency circle. Meanwhile, for workforce the supplier input resides within the regency and province circles, meaning that this input is taken from the outside, i.e. other regencies or provinces.

In the next production process, the need for raw material supply lies in two regional circles, i.e. inside Troso weaving cluster and in other regions outside the province. The availability of raw materials within Troso can be said as fewer than the input of raw materials from outside the cluster. For capital need, it can be seen that the capital resides in each type of indutries, namely large industries, medium industries and small industries. This indicates that the origin of capital is highly limited, which is even unfulfilled inside the cluster. The weaving product distribution process also passes through some phases, namely local market located in Troso, Jepara Regency, followed by regional market inside the provincial area, and the weaving products which reach international market (export) in the outermost circle.

The supporting factors of Troso weaving cluster in the development of weaving industry based on the research findings include (1) Local Government of Jepara which establish Troso Village as Weaving Industry Cluster Area because historically the people of Troso Village have been weaving since 1920. In this case, the Local Government of Jepara has established Troso Village as Tourism Village with Troso Weaving Attraction. (2) The social behavior of Troso Villagers still reflects rural culture, particularly coastal Javanese villages with various kinds of customs characterized mostly by Islamic culture. (3) The industries are located adjacent one another and they have this tendency of agglomerating, allowing each industry to enjoy the benefits existing within the cluster. (4) The workforce of these weaving industries amount to 1700 and most of them come from Troso. (5) The traditional weaving equipment develops and even evolves into ATBM or Alat Tenun Bukan Mesin (Non-Machine Weaving Tools) and is perfected to be semi-automatic ATBM.

As for the factors which obstruct the development of Troso weaving cluster are: (1) the efforts made to fulfill the industries' needs for capital mostly come from individuals, with the flow of incoming fund from the outside being impeded. (2) The management of companies is entirely held by their family, in this case it can be either the 
businessmen themselves, their wives, or their children. The modern company management has not been performed well and professionally. (3) The small industries sell their products outside the cluster with no price standard which in turn will impair the price. (4) For marketing their products, the businessmen rely too heavily on orders from traders and customers who come personally to buy Troso weaving products. (5) The relationship between these industries has not been optimal, while in fact a strong relationship between them will make them strong and leads to a more synergism within Troso weaving industry cluster.

\section{Conclusion}

The small, medium, and large industries form interrelated and both vertical and horizontal relationship patterns. The cluster strategy in the development of weaving industries as viewed from such aspects as businessman network, workforce, raw materials, supporting business location, production and post-production processes shows a contribution made by Troso weaving industry cluster in the form of the benefits obtained by business actors within the cluster. The supporting factors of Troso weaving cluster include the government, people's local wisdoms, location, availability of skilled workforce, and technology. Meanwhile, the obstructing factors of Troso weaving cluster are capital, industrial management performance, unfair competition, marketing, and relatively weak industrial relationship.

\section{References and Notes}

1. Kementrian Perdagangan RI, Pengertian Industri Kreatif, Retrieved from www.kemendag.go.id on September 20, 2017 (2012).
2. Godam, Faktor Pendukung dan Penghambat Industri Bisnis-Perkembangan dan pembangunan Industry Ilmu Sosial Ekonomi Pembangunan, Retrieved from http://organisasi.org Agustus 28, 2017 (2006).

3. Dinas Perindustrian dan Perdagangan Kabupaten Jepara, Potensi Industri Pengolahan Kabupaten Jepara, Jepara (2016).

4. Mei, Strategi Pengembangan Usaha Minimarket di Koperasi Mahasiswa (Studi Pada Koperasi Mahasiswa Universitas Sebelas Maret), Jurnal Dinamika Ekonomi Pendidikan 6, 2, [621-622] (2017).

5. Evi, Kajian Pola Keterkaitan Aktivitas Klaster Industri Tenun Troso Dalam Upaya Pengembangan Ekonomi Local Di Kabupaten Jepara, Jurnal Media Ekonomi dan Manajemen 23, 1 Januari (2011).

6. Porter, Cluster and the new economics of competition, Harvard Bussiness Review (1998).

7. M. Kuncoro, Analisis Spasial dan Regional: Studi Aglomerasi dan Kluster Industri Indonesia, Yogyakarta, UPP-AMP YKPN Press (2002).

8. A. Prastowo, Metode Penelitian Kualitatif dalam Perspektif Rancangan Penelitian, Yogyakarta, Ar-ruzz Media (2012).

9. Airlangga, Strategi Clustering dalam Industrialisasi Indonesia, Yogyakarta, Andi Offset (2004).

10. Alamsyah, Kearifan Lokal Pada Tenun Troso: Potret Kewirausahawan Pada Masyarakat Desa, Disertasi, Universitas Diponegoro (2013).

11. I. M. Wirartha, Metodologi Penelitian Sosial Ekonomi, Yogjakarta, CV Andi Offset (2006).

12. Jimly Asshiddiqie, Green Constitution, Nuansa Hijau Undang-Undang Dasar Negara Republik Indonesia Tahun 1945, Jakarta: Rajawali Pers (2010) 